\title{
FOREIGN TRADE OF AGRICULTURAL PRODUCTS BETWEEN SERBIA AND THE EUROPEAN UNION - PROBLEMS AND PERSPECTIVES
}

\author{
Ivana M. Božić Miljković1 \\ Singidunum University Belgrade, Serbia \\ Kristina Kaličanin \\ Singidunum University Belgrade, Serbia \\ Vladimir Mitić \\ Singidunum University Belgrade, Serbia
}

\begin{abstract}
The aim of this paper is to analyse trade relations between Serbia and the European Union, from the perspective of trade in agricultural products. An overview of the changes in the economic structure of Serbia, which resulted from the transition to a system of market economy and in which agriculture gained greater developmental significance than it had in the previous period, represents the starting point of the analysis. The trade of agricultural products between Serbia and the EU countries has been on an upward trend since the beginning of the century, and Serbia has achieved a positive balance in that trade. However, the structure of Serbian export points to a problem of low export competitiveness. This problem could be overcome by acting gradually on various segments of production, trade and promotion of agricultural products, which the authors of the paper define in the form of a proposal. Trade in agricultural products between Serbia and the EU is part of their overall economic relations and contributes to the process of Serbia's integration into the $E U$, so positive trends related to this aspect of their relations can be expected in the future.
\end{abstract}

Key words: foreign trade, agricultural products, Serbia, the European Union

\section{INTRODUCTION}

The structure of a country's foreign trade exchange is extremely important for its economy. From the standpoint of national economy, this structure has a developmental significance, pointing to the country's comparative advantages in international trade and encouraging the development of those industries that can make the greatest contribution to its economic growth and development. In the long run, the results achieved in foreign trade can significantly contribute to balancing the foreign trade balance and ensure macroeconomic stability of the national economy. From the standpoint of international economic relations, the structure of a country's foreign trade exchange indicates the degree of its economic development and the position it has compared to other countries and parts of the world. Taking into account the two sectormodel of the economy on which the basic model of a country's foreign

\footnotetext{
${ }^{1}$ ibozic(C) singidunum.ac.rs
}

Vol. 22, бpoj 1/2020, cmp. 29-46 
trade structure is traditionally based, we can start with a rough division of countries into those in which the structure of commodity exports is dominated by primary products while the import side is dominated by industrial products and countries that are recognized in international trade as exporters of industrial and importers of primary products. Serbia belongs to the first group of countries and, from the point of view of national and international economy, its structure of foreign trade is unfavorable. The deterioration of the exchange relations between Serbia and other countries occurred during the transition period, when, thanks to the privatisation, de-industrialisation and liberalisation of foreign trade, Serbia strengthened its position as an exporting country and opened its market for the import of final industrial products and products from high technology sector. In the structure of primary products exported by Serbia, agricultural and food products occupy a special place. Thanks to its geographic position and climate conditions favourable for the development of numerous agricultural products and breeding of domestic animals, Serbia has comparative advantages in the production of agricultural and food products in comparison to Western and Northern European countries, Russia and other parts of the world.

It is a known fact that European Union is Serbia's most important foreign trade partner and that Serbia realizes more than a half of its commodity exports and imports with countries which are members of the integration. The agri-food sector has a very important place and role in Serbia's trade with the EU and, besides, it represents an important aspect of their overall economic and other relations. As producers of agri-food products, Serbia and the EU hold very different positions, which has implications for their position in the international trade of this product group. While the European Union is recognised as a net exporter of agricultural products with very competitive prices in international trade, due to its protectionist policies and high subsidies in the area of agricultural production, Serbia does not have such privileges. The degree of modernisation of production of this group of products, including fruit and vegetable growing, viticulture and husbandry, is very low in Serbia and a large part of production is carried out extensively, which, from the aspect of preserving the quality of land, water and the air, can be an advantage, but, from the aspect of increasing productivity and economy of production, represents a disadvantage. Also, the absence of subsidies in production significantly limits the possibility of Serbia to follow the exporting price policy the way that the European Union does. The benefits granted to Serbia by the EU in the form of duty free export to its market have had a particularly favourable effect on the export of agrifood products. Over the last few years, Serbia has been making a surplus 
Foreign trade of agricultural products between Serbia and the European union..

in trade in this product group with the European Union, which contributes to its macroeconomic stability, as well as to the development of economic and other relations with the European Union, which can have positive effects on Serbia's sooner access to the European integration.

\section{LITERATURE OVERVIEW}

Agriculture has a great importance in Serbia's socio-economic development. That importance arises from the comparative advantages which Serbia has in the production of agricultural products, both those intended for human consumption and those which are intended for further industrial processing and which make the raw material basis for the development of other industries. Also, Serbia belongs to one of the Balkan countries where agricultural production represents traditionally the most important sector of the rural economy and the main source of income for the rural population (Bartlet, 2018, Matkovski et al, 2019). Serbia was recognized for its agricultural production in the second half of the 20th century, when it was a member of the former Yugoslavia. After the Second World War the share of agriculture in the overall structure of the economy was nearly 50\%, declining rapidly in the 1970s and 1980s in favour of increasing industrial share (Lafitić, 1997). The transition process, which formally began in Serbia in the 1990s and is still active, has led to a drastic decrease in the participation of industry in the economic structure of Serbia, with a slight increase in the participation of the primary sector and within it, agriculture. In the new condition, agriculture has been recognized as a new opportunity for the development of Serbian economy and one of the important export products (Božić, 2009; Udovički et al. 2019), especially to the EU market. Geographically, the EU and Serbia are close markets and foreign trade cooperation between them is part of a complex process of European integration and is intended to strengthen the overall economic and other forms of cooperation (Božić Miljković 2018; Međak 2018). In order to simulate trade with Serbia, the EU has unilaterally granted trade privileges for all industrial and agricultural products exported from Serbia to the European Union, except for a number of products that have for some time been excluded from the preferential tariff regime (Bjelić, 2012; Ristić \& Obradović, 2015; CCS). The positive effects of the preferential trade agreement are reflected in the positive balance achieved by Serbia in foreign trade in agricultural products with the European Union, which is illustrated in this paper in the data of relevant institutions dealing with the monitoring of foreign trade indicators of European Union foreign trade with other European and world countries (www.europa.rs). Newsletters

Vol. 22, бpoj 1/2020, cmp. 29-46 
issued by the European Union were also used to provide data on foreign trade in agricultural products with Serbia (Agri-Food Trade Statistical Factsheet). The problem of export competitiveness of Serbian agricultural products has been recognized and analysed by a large number of authors and their research results have been used in the paper. First of all, the low competitiveness is a consequence of the different approaches that the European Union and Serbia cherish in pursuing agricultural development policy (Maletić \& Popović, 2016; Marković et al, 2018; Wigier \& Kowalski 2018), but also the result of a wide range of development problems in agriculture - those inherited from the period of marginalization of the sector in favour of industrial development and those which are a product of the transition process (Radović, 2009; Stefanović \& Broćić, 2012). At the beginning of the $21^{\text {st }}$ century, in terms of agricultural production, Serbia is still a country of enormous potential and limited opportunities for their exploitation (Ševarlić, 2001; Bakrač et al, 2018; European Policy Centre). In addition to material investments, which are an imperative for the development of this industry in the future, there are various other ways to develop and promote agriculture. One way is to link agriculture and tourism through the promotion and sale of gastronomic specialties or touristic amenities that involve introducing tourists to local agricultural crops and the ways they used to be and are cultivated and processed now (Ristić et al, 2019).

\section{CHANGES IN THE STRUCTURE OF THE ECONOMY OF THE REPUBLIC OF SERBIA IN TRANSITION PERIOD}

In the period after the end of World War II until the 1990s, Serbia within the former Yugoslavia was remembered for its rapid economic development, which was based on the dynamic growth and development of industrial production. ${ }^{2}$ As a consequence, in the structure of foreign trade in goods the industrial sector has been dominant in the agricultural and forestry sector for many decades.

According to the presented data, we can conclude that in the observed period the biggest changes occurred on the export side of agricultural products. In pre-war years almost a half of Yugoslavia's total export (and within it Serbia's as well) were agricultural products. After the war, accepting industrialization as a new concept of economic development led to the marginalization of agricultural production and its

\footnotetext{
2 In the period from 1952 to 1990 , the average annual growth rate of industrial production and mining was $7.3 \%$, while agricultural production recorded an average annual growth of $3.1 \%$. (Latifić, 1997, 76).
} 
Foreign trade of agricultural products between Serbia and the European union..

neglect as a factor in the national economy development. ${ }^{3}$ The rapid development of industrial production resulted in major structural changes in the commodity exports of Yugoslavia, which were reflected in a significant decrease in the relative and absolute value of agricultural products in total export.

Table 1.: Structure of export and import by activities of the SFRY in \%

\begin{tabular}{|c|c|c|c|}
\hline & 1939 & 1974 & 1990 \\
\hline \multicolumn{4}{|l|}{ Export } \\
\hline Industry and mining & 52 & 91 & 97 \\
\hline Agriculture and forestry & 48 & 9 & 2 \\
\hline Other & - & - & 1 \\
\hline \multicolumn{4}{|l|}{ Import } \\
\hline Industry and mining & 91 & 90 & 92 \\
\hline Agriculture and forestry & 9 & 10 & 7 \\
\hline Other & - & - & 1 \\
\hline
\end{tabular}

Source: Latifić, 1997. Jugoslavija 1945-1990 (razvoj privrede i društvenih delatnosti). Beograd: Društvo za istinu o antifašističkoj NOB u Jugoslaviji, str.75

Entry into transition process, accompanied by turbulent political events on the one hand and by rapid and uncritical implementation of transition reforms on the other hand, led to the emergence of deep structural imbalances in the economic systems of the newly independent countries. In the initial period of the transition, with several neighboring countries, Serbia suffered a number of consequences that were the result of abandoning the well-known concept of development and unwillingness to switch to a market-based concept whose main determinants are competitiveness, investment and sustainability in a short space of time (Bartlett, 2018, 153). The negative effects of this period are still present today and they have consequences for the dynamics and quality of its economic growth and development. The process of de-industrialization which, in a negative sense, formed the backbone of the transition process in Serbia, contributed to the disruption of its macroeconomic stability, redefined its structure of commodity exports and thus conditioned the deterioration of its position in international economic relations. The process of de-industrialization in Serbia took place simultaneously with

\footnotetext{
${ }^{3}$ For example: Serbia's share in world agricultural added value in 1970 was $0.332 \%$, it reached a record share of $0.461 \%$ in 1977 , in 1980 it was $0.447 \%$, in 1990 it was $0.328 \%$, in 2000 it decreased to $0.194 \%$, and in 2010 it was reduces to $0.147 \%$ (www.makroekonomija.org accessed 02. Aug 2019)
}

Vol. 22, бpoj 1/2020, cmp. 29-46 
the process of trade liberalization, which influenced the structure of commodity exports in Serbia to be modeled on the model that distinguishes developing countries. Particularly negative effects were manifested in the structure of commodity exports which, year after year, made it increasingly clear that industrial products originating in Serbia were declining in competitiveness, having more difficulty in penetrating foreign markets with its quality, while primary products were recording an increasing share. That problem is as present in Serbian economy today as it was three decades ago when Serbia entered the transition process.

Along with the process of de-industrialization in Serbia, the demand for raw materials and semi-finished products was growing in the global market. Export of these products became a new development opportunity for Serbia, that is, a new development ultimatum imposed on them in the current conditions (Božić, 2009, 81). Orientation towards the export of primary products, in a very short time, removed Serbia away from the status of exporter of industrial products, which it had in the pretransition period, but also opened new perspectives for future development. The revitalization and modernization of the agrarian sector were being increasingly promoted as a new development opportunity and agricultural products were, under the circumstances, recognized as one of the potential export assets of the Republic of Serbia.

Despite the fact that Serbia has very favorable climate and other conditions for the development of agriculture and the development of the processing industry in that area, no significant results have been achieved in terms of production and exports in the past thirty years. Serbia, a country that by virtue of its economic structure belongs to the group of agro-industrial countries, has so far failed to adequately integrate agriculture into the overall development of the economy and redesign its transformation process in accordance with standards applicable in Western European countries, which created some problems. First of all, even in the $21^{\text {st }}$ century Serbia's agriculture is characterized by a large number of smallholder farms. In this case, the small size of land is a limiting factor in the application of modern agro-technical measures, which calls into question the efficiency of production (Maletić \& Popović, 2016, 811). Secondly, the modernization of agricultural production capacities proceeded very slowly, because during the entire second half of the $20^{\text {th }}$ century, agriculture in Serbia was a "bottleneck" of the development of the entire economy, primarly due to the limited and outdated production capacities and labor shortages. Also, the 1999 NATO aggression againts the Republic of Serbia, in which uranium depleted bombs were used, has left many consequences for the ecosystem (Bakrač et al, 2018, 484-485). Therefore, the quality of products produced on 
Foreign trade of agricultural products between Serbia and the European union..

contaminated land is potentially questioned, which could directly affect foreign demand for these products and impose the need for special health controls (Ševarlić, 2001, 10). Finally, economic policy measures were not stimulating to encourage the development and improvement of agricultural production; on the contrary, they were predominantly oriented towards stimulating the development of other areas of the primary sector or revitalizing some industrial capacities which, under the auspices of large foreign companies, produced lower-grade industrial products or were engaged in assembly and finishing operations. At the beginning of this century, all of the above caused the importance of agriculture in relation to other sectors of the economy to be underestimated in terms of creating an adequate development strategy and investing in development and modernization.

\section{FOREIGN TRADE OF AGRICULTURAL PRODUCTS BETWEEN SERBIA AND THE EUROPEAN UNION}

A new history of foreign trade relations between Serbia and the European Union dates back to the very beginning of the $21^{\text {st }}$ century, when, after a decade of political conflicts, economic sanctions, the collapse of the domestic economy and aggression by NATO, Serbia's political and economic relations with Europe and the world normalized. Since then the relations between Serbia and the European Union, from the perspective of their mutual trade, have been part of the place and position that the European Union has in the international trade, but also of the policy it pursues towards Serbia as a country that is in the process of European integration and has strong aspirations for European Union membership. Serbia, on the other hand, had to adapt its traditionally oriented foreign trade towards the countries of Western Europe and the European Union to the new conditions arising from the process of European integration, as well as to the conditions dictated by the processes in the global economy. One of them is a membership in the World Trade Organization, which is directly conditioned by the adoption of appropriate laws for the production and marketing of GMO-labeled products (European Policy Centre https://cep.org.rs/en/blogs/gmo-whatsthe-catch/). The first move the European Union made to stimulate trade with Serbia was the unilateral approval of trade privileges for all the industrial and agricultural products exported from Serbia to the European Union. ${ }^{4}$ By signing this Agreement, Serbia was given the opportunity to

\footnotetext{
${ }^{4}$ The regime unilaterally granted by the European Union to Serbia in 2000 was the most extensive system of trade preferences ever granted to a country or a group of countries
}

Vol. 22, бpoj 1/2020, cmp. 29-46 
export to the European Union market, duty-free and without quantitative restrictions, all industrial and agricultural products, except for a small number of agricultural products subject to the preferential tariff regime and the quotas prescribed therein. ${ }^{5}$ Thanks to the implementation of this Agreement, Serbia has been recording a positive balance of agricultural trade with the European Union since 2005. In addition to the expected positive effects of the Agreement on trade in agricultural products, the Agreement regulates a number of systematic issues in agriculture in a manner adapted to Serbia, which is in accordance with the relevant European legislation (Međak, 2018, 127). Although Serbia has had candidate status for many years, radical reform in the field of agricultural production has not been implemented yet and it represents a great challenge for those who are directly involved in the process of production, processing and storage of food, but also for all those who have an indirect connection with this sector.

Table 2.: Foreign trade of agricultural products between Serbia and the European Union

\begin{tabular}{|c|c|c|c|c|c|c|c|}
\hline & 2005 & 2007 & 2009 & 2011 & 2013 & 2015 & 2017 \\
\hline $\begin{array}{c}\text { Export } \\
\text { to EU }\end{array}$ & 509.1 & 725.80 & 922.78 & $1,345.55$ & $1,122.11$ & $1,214.41$ & $1,282.54$ \\
\hline $\begin{array}{c}\text { Import } \\
\text { from } \\
\text { EU }\end{array}$ & 364.3 & 331.04 & 398.08 & 634.83 & 760.02 & 838.37 & 945.01 \\
\hline Balance & 144.8 & 394.76 & 524.7 & 710.72 & 362.09 & 376.04 & 337.53 \\
\hline
\end{tabular}

Source: https://europa.rs/serbia-and-the-eu/trade/serbia-eu-trade-in-agriculturalproducts/?lang=en

Throughout the period under review, Serbia has achieved a positive foreign trade balance in the exchange of agricultural products with the European Union. The largest surplus was recorded in 2011 and the surplus values at the end of the observed period are almost 2.5 times higher than those recorded at the beginning of the observed period. Such positive trends in the exchange of agricultural products between Serbia and the European Union result from the implementation of the provisions of the Agreement. However, the entry into force of the Agreement's

by the European Union. Delegation of the European Union in Serbia https://europa.rs/srbija-i-evropska-unija/trgovina/

${ }^{5}$ In particular, the preferential tariff regime applied to sugar, beef, wine and several types of fish. (Ristić \& Obradović, 2015,97) 
provision, along these positive effects, has revealed a wide range of deficiencies and problems that Serbia has in developing the agricultural sector. Some of those problems are inherited from the period of rapid industrialization and some are the result of recent history and are related to the state's attitude to the development of the agrarian sector and the place which that sector has within economic policy. Regardless of the period in which they arose, those problems further emphasize the inferior position of the Serbian agrarian sector in relation to the one existing in the European Union, which is implemented under the auspices of the Common Agricultural Policy (CAP).

The Common Agricultural Policy of the Member States of the European Union was established in the late 1950s. Since then, it has evolved and changed in accordance with the needs and problems of countries that have different traditions in the development of the agrarian sector, a different relation in terms of priorities that the agrarian sector has in the overall economic development and different development resources (Wigier \& Kowalski 2018, 117). In a short time, the Common Agricultural Policy has become globally recognized as an example of a successful policy in the field of agricultural production. The determinants of these policies are high allocations from the Union budget for agricultural development, high subsidies to farmers and other forms of support related to the modernization and improvement of production and supply of input. More recently, in line with new needs and market demands, a new CAP reform has introduced support systems that will encourage manufacturers to orient their production to market needs and take greater account of environmental issues (Marković et al. 2018, 487). Such a policy had, and still has, a stimulating effect on the growth of production and export of agricultural products in the European Union, that is, it ensures the expansion of the European Union's leading position in international trade in agricultural products. The European Union has achieved such positions, and defends them today, with a high competitiveness that these products have on the world market.

Unlike the European Union, the agricultural sector in Serbia has been affected by the transition process since the 1990s. The basic measures of the development of the agrarian sector within the transition process were nor significantly different from those set for other sectors of the economy. At the beginning of this century, new forms of state aid were introduced into the agrarian budget, which should facilitate the operations of the agrarian sector in accordance with market demands. State aid is provided in the form of financial and non-financial incentives for the development of the agricultural market, incentives for rural development, credit support for agricultural development and even grants 
for development projects of exceptional importance. Obviously, premiums and other incentives can be obtained only by registered agricultural holdings, the number of which is far lower than the total number of agricultural producers (Simonović et al. 2017, 255). However, all these incentives did not contribute to the expected development of the agrarian sector in Serbia, that is, they did not bring it closer to the model existing in the European Union in terms of development. ${ }^{6}$ This is also indicated by the structure of trade in agricultural products between Serbia and the European Union, that is, the structure of agricultural exports that Serbia launches on the European Union market, which is predominantly represented by raw and frozen agricultural products and far less by processed fruit and vegetable products, even though there is a demand for such products in the European Union (Udovički et al, 2019, 9).

Graph 1.: Structure of Serbian agricultural exports to the European Union in 2018 in million euro and \%

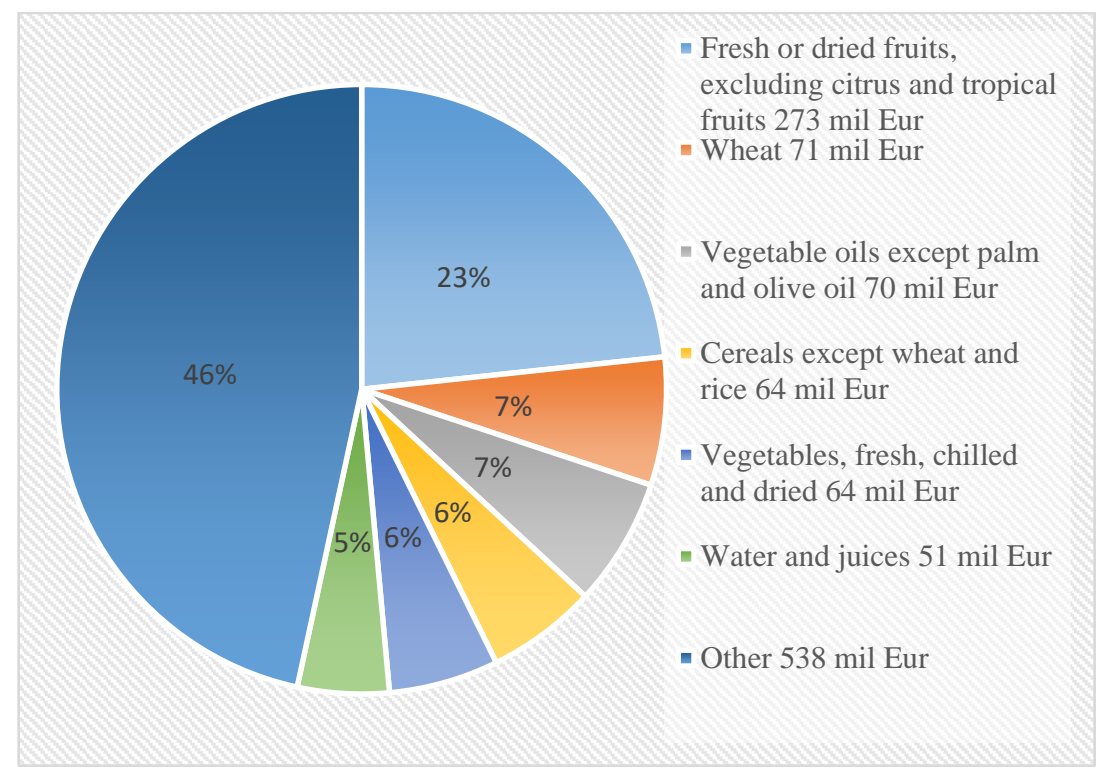

Source: Agri-Food Trade Statistical Factsheet. EU Agri-Food Trade with Serbia. p. 6

\footnotetext{
${ }^{6}$ For example, in the European Union, which, as of 2006, consisted of 25 countries with a total population of 480 million, an average subsidy per capita in that year was $€ 127$. In our country, in the same period, subsidies to agricultural producers averaged 17 to 20 euros, in neighboring Hungary 70 euros and in Slovenia as much as 130 euros per capita. In terms of hectares, subsides in the European Union amounted to 360 euros in 2006, and 32 euros per hectare in our country. We can conclude that our agrarian has almost ten times less state support compared to developed countries. (Radović, 2009, 70)
} 
Foreign trade of agricultural products between Serbia and the European union..

Such a structure of Serbian exports of agricultural products to the European Union is a consequence of insufficient investment in the development of the agricultural sector, insufficient investment in the modernization of fruit and vegetable processing capacities and decades of neglect of innovation and knowledge as a development resource in agriculture. To the Serbian economy, exports of processed agricultural products would mean higher export revenues than those generated by exports of fresh and frozen agricultural products. Improving the structure of exports towards a greater share of processed products from fruits, vegetables and cereals, besides the above mentioned investments, implies also meeting the strict standards that the European Union imposes on producers, both in production and processing. Adopting European Union standards in this area is one of the segments of comprehensive alignment of national agricultural policy with EU agricultural policy and is an integral part of the European integration process.

Graph 2.: Structure of Serbian imports of agricultural products from the European Union in 2018 in million euro and \%

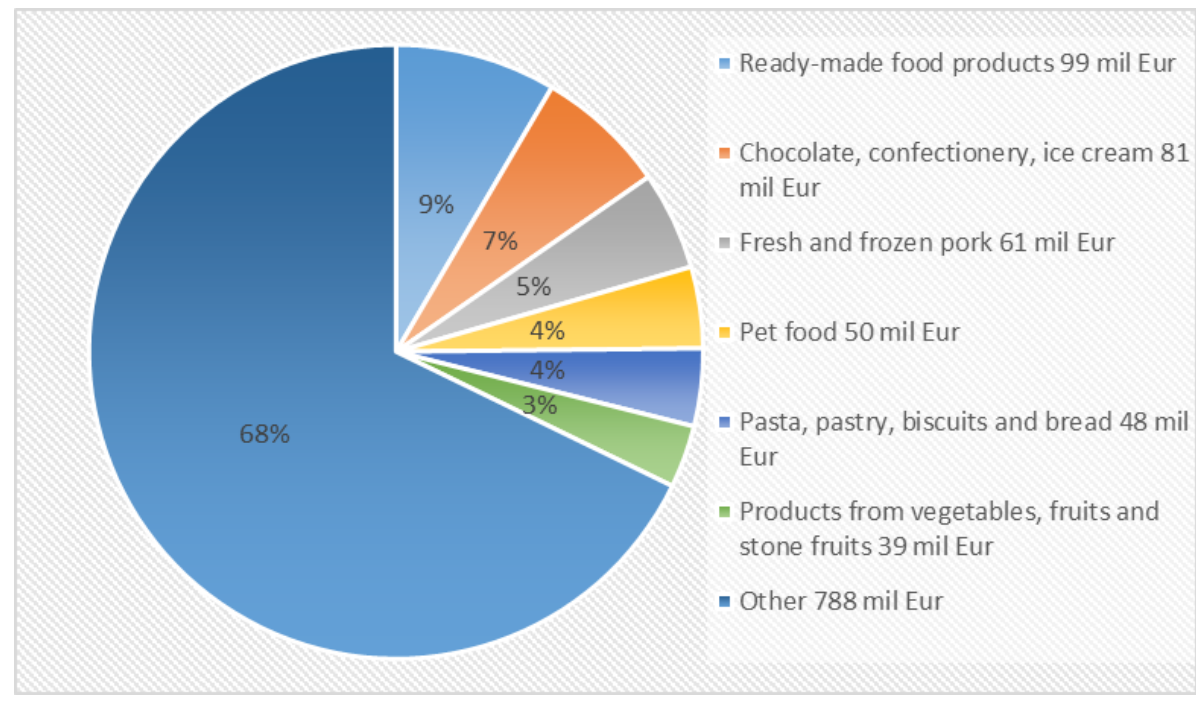

Source: Agri-Food Trade Statistical Factsheet. EU Agri-Food Trade with Serbia. p. 4

The structure of Serbian imports from the European Union is dominated by ready-made food products, whereas raw agricultural products are only slightly present. Such a structure of imports reflects differences in the development of the agricultural sector and it is a consequence of the complete liberalization of imports from the European

Vol. 22, бpoj 1/2020, cmp. 29-46 
Union, which entered into force in Serbia in $2014 .^{7}$ In terms of the Serbian economy, the unfavorable structure of foreign trade in agricultural products with the European Union also reflects the problem of low export competitiveness, which is present in all segments of foreign trade, including the exchange of agricultural products. In addition to the problem of low export competitiveness, the future exchange of agricultural products of Serbia and the European Union will also be conditioned by geopolitical factors, such as relations between the European Union and the Russian Federation and the position Serbia occupies in these relations. ${ }^{8}$ It is well known that the terms of trade of the European Union with countries outside the European Union are regulated by the common foreign trade policy (Bjelić, 2012, 471). Since it is not a member of the European Union, Serbia has no formal legal obligation to join the measures taken by the European Union, but as a candidate country it is expected to align its foreign policy with the European Union and to support the European Union in the measures taken.

\section{PROBLEMS OF COMPETITIVENESS OF DOMESTIC AGRICULTURAL PRODUCTS ON THE EUROPEAN MARKET}

Foreign trade liberalization in Serbia has led to an increase in foreign trade in agricultural and food products, which has made the problem of low competitiveness of agricultural exports and imposed the need to improve that competitiveness visible. The absence of major investments in the agricultural sector in Serbia in the second half of the twentieth century, as well as in the most of the Southeast European countries belonging to the group of post-socialist countries, caused many development problems. These problems came to the fore in the first years of transition and manifested themselves, primarily within the agricultural

\footnotetext{
7 In 2000, the EU authorized the export of customs-free food from the Republic of Serbia, except for wines, fish and beef, for which there are quantitative quotas, and sugar, which has a special quota. As of January $30^{\text {th }} 2009$, Serbia unilaterally implemented the Interim Trade Agreement with the EU. Within this framework, the Republic of Serbia was gradually, with a six-year term, lowering customs duties on products imported from the EU. The imports from the EU were fully liberalized at the beginning of 2014. The exception is certain agricultural products, which will retain a certain level of customs protection until full membership of the Republic of Serbia in the EU - tobacco, cigarettes, sour milk, dairy spreads, margarine, waffles, certain alcoholic beverages and more. (Serbian Chamber of Commerce, www.pks.rs Acessed: 18 July 2019)

${ }^{8}$ Relations between the European Union and Russia have been strained since 2014, when the European Union imposed sanctions on Russia due to the annexation of Crimea to Russia and conflicts in Ukraine.
} 
sector itself, and then their negative impact was reflected on the entire economy (Matkovski et al. 2019).

The basis of the low export competitiveness of Serbian agricultural products lies in the unfavorable export structure dominated by raw agricultural products or products with a lower level of processing. In addition, low export competitiveness is also determined by a number of factors, the most important of which are: high dependence of yield on climatic conditions; extensive production factors, the most significant of which are: labor, land and water; low level of implementation of scientific and technological achievements in agricultural production; dominant participation of small producers in the structure of agricultural production; a pricing policy for agricultural products which is significantly different from that applied by the European Union, as well as non-price factors of competitiveness: packaging, design, technical standards, durability and preservation of freshness of products, promotion of products on the market, etc. (Stefanović \& Broćić, 2012, 270). Measures to improve competitiveness in Serbia must be implemented gradually and their implementation requires material assistance from both the state and European funds, which are more accessible to Serbia as a candidate country for EU membership than to some of the neighboring countries that are part of the integration. The liberalization of trade in agricultural products contributes to the growth of competitiveness and, from this point of view, diversification of export activities on markets outside the European Union is necessary as well.

Some of the proposals for improving the competitiveness of export of agricultural products originating in Serbia to the European Union and other markets would be:

First, investments should occupy a far more significant place in financing agricultural production than it has been a case so far. Permanent investment in all stages of production, processing and marketing of agricultural products - especially those intended for human consumption can significantly improve the competitiveness of domestic agriculture as a whole;

Second, as the agrarian sector is not independent of other sectors of the economy, but in cooperation with them constitutes the economic structure of the country and traces its economic development, investments in the agricultural sector must be accompanied by comprehensive structural reforms similar to those implemented in successful European economies;

Third, the EU market is attractive to Serbian agricultural exporters in many aspects; however, in order to increase export competitiveness, a greater diversification of agricultural exports from Serbia is the 
imperative. Namely, maintaining a significant share of exports of agricultural products to the markets of Russia, Belarus and Kazakhstan, with which Serbia has signed agreements on duty-free exports, is imperative for the future (Božić Miljković, 2018, 111). Serbia's membership in the European Union will put an end to these agreements and Serbia will accept the trade regime which the European Union has with those countries. This will adversely affect the competitiveness of Serbian agricultural products on the Russian market and the markets of Belarus and Kazakhstan;

Fourth, a completely new organization of the agricultural market needs to be created in order to reduce demand-side monopolies, thus ensuring price stability and mitigating the differences in price policy applied in this area by Serbia and the European Union;

Fifth, the production of agricultural products should be structured according to the requirements of import demand, with a particular focus on a higher share of those products that are authentic Serbian products, i.e. products with a designation of geographical origin, such as: honey, aromatic and medicinal herbs, home-grown fruit and vegetable products, wines from local grape varieties, etc. (Ignjatijević \& Cvijanović, 2018, 111);

Sixth, exploiting geographical and climatic advantages in agricultural production, the following should be taken into account: technological modernization of capacities, employment of more educated personnel in the field of agriculture and improvement of organizational structure and management, and

Seventh, it is necessary to show a greater degree of creativity in the use of agro-tourism resources in Serbia, i.e. to link the tourist offer with various aspects of agriculture. An integral part of the tourist offer may be authentic gastronomic specialties, organized visits to plantations where certain crops are grown or production capacities for processing fruits and vegetables, promotion of old crafts, etc. In this way, more promising directions for the integral development of agriculture and tourism are achieved on a sustainable basis (Ristić et al., 2019, 58).

The structure of exports of agricultural products from Serbia in the future should change in the direction of greater share of processed products compared to fresh and frozen products and in the direction of export orientation to the wider market. In implementing measures and recommendations for the improvement of competitiveness, world and European knowledge and experience, especially from countries that are recognized as successful exporters of agricultural products in international trade, can be of benefit to Serbia. 
Foreign trade of agricultural products between Serbia and the European union..

\section{CONCLUSION}

In the post-World War II period, today's post-socialist countries, including Serbia, have used methods of industrialization in their economic development. In the structure of the economy, industry had a dominant share while the primary products sector was marginalized and with a steady decline in share. The decline in agricultural production resulted in drastically smaller share in the structure of exports. In the early 1990s, thanks to the transition process and its integral parts: deindustrialization, privatization and liberalization, the primary sector and, within it, the agri-food sector, were again given a chance to increase their share in GDP creation and were promoted as one of the most important export assets of the Republic of Serbia. However, the consequences of decades of agricultural marginalization, modest investment in modernization and technological development of production capacities, lack of skilled and educated workforce, caused Serbia to be recognized as an exporter of raw and frozen agricultural products in international trade, with a very small share of higher processing products. Serbia's position in foreign trade in agricultural products is most prominent in this segment of trade with EU countries. Despite the fact that Serbia has been in surplus in agricultural products trade with the European Union over the last 15 years, the structure of that trade, which is dominated by raw agricultural products, points to the problem of Serbia's low export competitiveness in this area.

When it comes to the agricultural development policy and the treatment that agricultural producers receive from the state or supranational body, Serbia and the European Union cannot be compared. However, as a candidate country, Serbia has access to a number of EU funds that can be used to advance the development of the agricultural sector. Serbia can also benefit from duty-free exports of agricultural products to the EU market. Given that Serbia also has such agreements with Russia, Belarus and Kazakhstan, the dynamic of future cooperation in this area between Serbia and the European Union will be conditioned by geopolitical circumstances in Europe. The measures that Serbia needs to take in order to improve the production and export of agricultural products, especially to the EU market, are not simple and the effects of their implementation cannot be visible in the short term. This, primarily, refers to the necessity for modernization and technological upgrading of agricultural production capacities, ensuring product certification, harmonization of production with the structure of import demand and provision of highly skilled personnel in this area, and, to the extent possible, reducing the dependence of agricultural production on climate

Vol. 22, бpoj 1/2020, cmp. 29-46 
change. What is also very important is the abolition of demand-side monopolies and greater diversification of exports in terms of Serbia's greater orientation toward selling its agricultural products on the markets of non-EU countries. In order to develop this sector of the economy, Serbia can use its experiences from the previous period, as well as the experiences of other countries in transition - those that have successfully completed this process and those where the process is still ongoing.

\section{LITERATURE}

1. Bakrač, S, Klem, E. \& Milanović, M. (2018). Ekološke posledice NATO bombardovanja Republike Srbije 1999. godine. Vojno delo, 70(7), 475-492.

2. Bartlett, W. (2018). Economic Reforms in Serbia and Prospects for Economic Recovery and Growth. In: (eds. Osbild, R. \& Bartlett, W.) Western Balkan Economies in Transition: Recent Economic and Social Developments. Springer Publications. pp. 147-163

3. Bjelić, P. (2012). Uključenje Srbije u jedinstven spoljnotrgovinski režim Evropske unije. U: (ur. Dimitrijević, D. \& Miljuš, B.) Harmonizacija zakonodavstva Republike Srbije sa pravom Evropske unije (II). Beograd: Institut za međunarodnu politiku i privredu i Fondacija Hanns Seidel Stiftung. pp. 456-472.

4. Božić Miljković, I. (2018). Ekonomije balkanskih zemalja na početku XXI veka. Beograd: Institut za međunarodnu politiku i privredu.

5. Božić Miljković, I. (2018). Economic Cooperation Between Serbia and the Member States of the Eurasian Economic Union: Constraints and Potentials. Eurasian Journal of Business and Economics 11(22), 105-121.

6. Božić, M. (2009). Deindustrijalizacija zemalja u tranziciji i njene ekonomske posledice. Teme 33(2), 423-442.

7. European Delegation in Serbia: Agri-Food Trade Statistical Factsheet. EU Agri-Food Trade with Serbia.

8. Ignjatijević, S. \& Cvijanović, D. (2018). Exploring the Global Competitiveness of Agri-Food Sectors and Serbia's Dominant Presence: Emerging Research and opportunities. USA: IGI Global.

9. Latifić, I. (1997). Jugoslavija 1945-1990 (razvoj privrede i društvenih delatnosti). Beograd: Društvo za istinu o antifašističkoj NOB u Jugoslaviji. 
Foreign trade of agricultural products between Serbia and the European union..

10. Maletić, R. \& Popović, B. (2016). Production Capacity of Family Farms in Serbia and EU Countries. Teme, 40(2), 807-821.

11. Marković K, Njegovan, Z, \& Pejanović, R. (2018). Former and Future Reforms of Common Agricultural Policy of the European Union. Ekonomika poljoprivrede 59(3), 483-498.

12. Matkovski, B, Kalaš, B, Zekić, S. \& Jeremić, M. (2019). AgriFood Competitiveness in South East Europe. Outlook on Agriculture, 48(4), 326-335.

13. Međak, V. (2018). Effects of Stabilization and Association Agreements and CEFTA 2006 on WB6 European Integration and Regional Cooperation: Achievements and Ways Forward. Belgrade: European Movement in Serbia and Embassy of Federal Republic of Germany in Belgrade.

14. Radović, G. (2009). Podrška države u funkciji finansiranja poljoprivrede. Agroekonomika, 41-42, 69-79.

15. Ristić L. \& Obradović S. (2015). Mogućnosti i ograničenja izvoza agrarnih proizvoda Republike Srbije na tržište EU. u: (red. Jakšić, M, Stojanović Aleksić, V. \& Mimović, P.) Ekonomsko-socijalni aspekti priključivanja Srbije Evropskoj uniji. pp. 93-103.

16. Ristić, L, Bošković, N. \& Despotović, D. (2019). Održivi integralni razvoj poljoprivrede i turizma u Republici Srbiji. Ekonomski horizonti, 21(1), 57-74.

17. Simonović, Z, Mihailović, B, \& Ćurčić, N. (2017). Struktura poljoprivrednih gazdinstava u Republici Srbiji prema površini poljoprivrednog zemljišta. Poslovna ekonomija, 11(2),.247-259.

18. Stefanović, R. \& Broćić, Z. (2012). Kvalitet kao determinanta rasta izvoza poljoprivredno prehrambenih proizvoda Republike Srbije FQ 2012 - Festival kvaliteta, A267-A273. Dostupno na: http://www.cqm.rs/2012/cd1/pdf/39/33.pdf (accessed on 2 Aug 2019)

19. Ševarlić, M. (2001). Posledice NATO agresije u poljoprivredi i prehrambenoj industriji SR Jugoslavije. Ekonomika poljoprivrede 47(1-4), 3-16.

20. Udovički, K, Medić, P, \& Avlijaš, S. (2019). Competitiveness of Serbia's Economy in the Context of New Global Economy: Opportunities and Threats. Belgrade: Public Policy Research Center.

21. Wigier M. i Kowalski A. (2018). The Common Agricultural Policy of the European Union - the Present and the Future. EU Member States Point of View. Warsaw: Institute of Agricultural and Food Economics. 
22. https://cep.org.rs/en/blogs/gmo-whats-the-catch/ (accessed on 30 Jul 2019)

23. http://www.pks.rs (accessed on 18 Jul 2019)

24. http://www.makroekonomija.org (accessed on 2 Aug 2019)

25. https://europa.rs/serbia-and-the-eu/trade/serbia-eu-trade-inagriculturalproducts/?lang=en (accessed on $17 \mathrm{Jul} 2019$ )

Рад је примьен: 16.09.2019.

Рад је прихваћен за итампу: 20.11.2019. 